\title{
Hemşirelik ve Ebelik Öğrencilerinin COVID-19 Pandemi Sürecindeki Uzaktan Eğitime Yönelik Görüş ve Önerileri
}

\section{Views and Suggestions of Nursing and Midwifery Students for Distance Education in the COVID-19 Pandemic Process}

\author{
Nurten Terkeş ${ }^{1}$ (i) Sabriye Uçan Yamaç ${ }^{2}$ (iD) \\ ${ }^{1}$ Burdur Mehmet Akif Ersoy Üniversitesi Bucak Sağlık Yüksekokulu, Hemşirelik Bölümü, İç Hastalıkları Hemşireliği Ana Bilim Dalı, Burdur, \\ TÜRKIYE \\ ${ }^{2}$ Burdur Mehmet Akif Ersoy Üniversitesi Bucak Sağlık Yüksekokulu, Ebelik Bölümü, Burdur, TÜRKIYE \\ Geliş tarihi/ Date of receipt: 12/01/2021 Kabul tarihi/ Date of acceptance: 21/04/2021 \\ (c) Ordu University Faculty of Health Sciences, Department of Nursing, Turkey, Published online: 08/09/2021
}

ÖZ

Amaç: Hemşirelik ve ebelik öğrencilerinin COVID-19 pandemi sürecindeki uzaktan eğitime yönelik görüş ve önerilerini belirlenmektir. Yöntem: Tanımlayıcı tipteki bu araştırmanın örneklemini ülkemizin devlet üniversitelerinin hemşirelik ve ebelik bölümlerinde eğitim gören 1476 öğrenci oluşturdu. Araştırma verileri Ağustos-Aralık 2020 tarihlerinde, Google Formlar üzerinden online olarak toplanmıştır. Araştırmanın verileri, literatür doğrultusunda araştırmacılar tarafından geliştirilen öğrencilerin pandemik süreçteki uzaktan eğitim ile ilgili görüşlerini içeren bir anket formu ile toplanmıştır. İstatistiksel analizler SPSS 21 paket programı ile yapılmıştır. Etik Kurul'dan ve Sağlık Bakanlı̆̆ı'ndan onay alınmıstır.

Bulgular: Araştırmaya katılan öğrencilerin \%54.2'sinin uzaktan eğitimde uygulanan ders anlatım yöntemlerinden canlı ders anlatımlarını daha yararlı bulduğu belirtilmiştir. Katılımcıların \%68.7'sinin uzaktan eğitim derslerinin tamamını izleyemedikleri, izleyememe nedenleri; \%41.2'sinin ev ortamında derse konsantre olamaması, \%31'inin derslere verdikleri önemin azalması, \%27'sinin başka sorumluluklarının olduğu ifade edilmiştir. Bu süreçte katılımcıların \%84'ünün en az bir defa teknik sorun yaşadığı, yaşanan teknik problemler; görüntü donması (\%60.9), ses gelmemesi (\%59.9) ve internet bağlantısının kopması (\%55.3) olarak belirtilmektedir. Öğrencilerin \%23.4'ünün üniversitenin sağladığı uzaktan eğitim hizmetinden memnunken, \%32.7'si kararsız olduğunu ifade etmiştir.

Sonuç: Hemşirelik ve ebelik öğrencilerinin uzaktan eğitimde derslere etkin katılım sağlayamadığı ve birçok teknik problemlerle karşılaştığ1 görülmektedir. Öğrencilerin uzaktan eğitimden daha iyi fayda sağlayabilmeleri için alt yapı değişikliklerinin ve gerekli teknolojik desteğin sağlanması gerektiği düşünülmektedir.

Anahtar Kelimeler: Hemşirelik öğrencileri, ebelik öğrencileri, COVID-19, pandemi, uzaktan eğitim

\begin{abstract}
Objective: To determine the views and suggestions of nursing and midwifery students for distance education in the COVID-19 pandemic process.

Methods: The sample of this descriptive study was composed of 1476 students studying at the nursing and midwifery departments of our country's state universities. The research data were collected online via Google Forms between August-December 2020. The data of the study were collected with a questionnaire form developed by the researchers in line with the literature, which includes the views of students about distance education in the pandemic process. The statistical analyses were conducted with the SPSS 21 package program. Approval was obtained from Etics Committee and Ministry of Health.

Results: It was stated that $54.2 \%$ of the students participating in the study found live lectures more useful than the lecture methods used in distance education. $68.7 \%$ of the students in the study could not watch all of the distance education lessons, when looking at the reasons for not being able to watch, it is seen that $41.2 \%$ of them could not concentrate on the lesson in the home environment, $31 \%$ of them decreased the importance they give to the lessons, and $27 \%$ of them could not watch because they have other responsibilities. In this process, $84 \%$ of the participants experienced technical problems at least once, technical problems; image freezing (60.9\%), no sound (59.9\%) and internet connection lost $(55.3 \%)$. While $23.4 \%$ of the students were satisfied with the distance education service provided by the university, $32.7 \%$ of them were undecided.

Conclusion: Nursing and midwifery students can't actively participate in distance education lessons and encounter many technical problems. It is thought that infrastructure changes and necessary technological support should be provided in order for students to benefit better from distance education.
\end{abstract}

Keywords: Nursing students, midwifery students, COVID-19, pandemic, distance education

\footnotetext{
ORCID IDs of the authors: NT: 0000-0002-1644-8382; SUY: 0000-0002-3932-8017

Sorumlu yazar/Corresponding author: Dr. Öğr. Üyesi Nurten Terkeş

Burdur Mehmet Akif Ersoy Üniversitesi, Bucak Sağlı Yüksekokulu, Hemşirelik Bölümü, İç Hastalıkları Hemşireliği Ana Bilim Dalı, Burdur, TÜRKIYE

e-posta/e-mail: nurtenterkes@gmail.com

Atıf/Citation: Terkeş N, Uçan Yamaç S. (2021). Hemşirelik ve ebelik öğrencilerinin COVID-19 pandemi sürecindeki uzaktan eğitime yönelik görüş ve önerileri. Ordu Üniversitesi Hemşirelik Çalışmaları Dergisi, 4(2), 240-247. DOI:10.38108/ouhcd.858820
} 


\section{Giriş}

Aralık 2019'un başlarında, Çin'in Hubei eyaletinin Wuhan şehrinde SARS-CoV-2'nin (corona virüsü 2) neden olduğu ifade edilen 2019 korona virüsü (COVID-19) ortaya çıkmıştır. O tarihten itibaren, yerel ve ulusal hükümetler, hastalığın patlak vermesine yanıt olarak sosyal ve ekonomik alanlarda önlemler almaya başlamıştır (Zhu ve ark., 2020; Chen ve ark., 2020). Çin'den sonra Avrupa ülkelerinde de görülmeye başlayan pandemik süreç, 11 Mart'ta ilk vakanın görülmesiyle birlikte resmi olarak ülkemizde de başlamıştır (TCSB, 2020). COVID-19 sonrasında ulaşım, sağlık, kültür, gıda, turizm, finans, ekonomi vb. birçok alanla birlikte etkilenen alanlardan birisi de eğitimdir. Eğitim için alınan ilk önleme baktığımızda, okullar kapatılarak eğitime ara verilmesidir. Ancak COVID-19'un etkileri arttıkça eğitime kısa süreli ara vermenin yeterli olamayacağı anlaşılmış ve pandemik süreç durulana kadar eğitim sürecinin uzaktan eğitimle yürütülmesine yönelik planlamalar yapılmıştır (Kurnaz ve Serçemeli, 2020; Viner ve ark., 2020). Alinan bu kararlara, üniversiteler de uzaktan eğitim merkezleri aracılığıyla hızlı bir șekilde uyum sağlayarak eğitime başlamışlardır (Kurnaz ve Serçemeli, 2020; Zhong ve ark, 2020).

Pandemi nedeniyle zorunlu olarak girilen bu süreçte, eğitimin her basamağında şartlar değerlendirilerek gerekli tedbirler alınmaya çalışılmıştır. Eğitim sürecinin içinde bulunan öğretmenler, akademisyenler, öğrenciler ve veliler daha önce hiç yaşamadıkları yeni bir deneyimle baş başa kalmışlardır. Ayrıca "değişen dünyanın eğitim sistemine" bir anda uyum sağlamak zorunda kalmışlardır (Zan ve Zan, 2020). Bu durum beraberinde birtakım problemleri ya da avantajları getirmiştir. Bazı üniversiteler uzaktan eğitim yöntemi olarak çevrimiçi senkron, bazıları çevrimdışı asenkron ve bazıları da karma yöntemleri kullanmayı tercih ederken, derslerin işlenme şekillerinin ise bazı birimlerde öğretim elemanının kendi istediğine bırakıldı ğ belirtilmektedir (Kurnaz ve Serçemeli, 2020; Zan ve Zan, 2020).

Hemşirelik ve ebelik eğitimi açısından bakıldığında, teorik ve uygulama eğtiminin eşit öneme sahip olduğu aşikardır. $\mathrm{Bu}$ nedenle uygulamalı eğitime sahip olunan birimlerde uzaktan eğitimin tek başına kullanılamayacağı, örgün öğretimi destekleyici nitelikte yaşam boyu öğrenme ilkesine uygun şekilde kullanılabileceği ifade edilmektedir (Öztürk, 2015). Ancak yüz yüze eğitimin yapılamadı̆̆ 1 bu pandemik süreçte, eğitim sürecini etkin yönetebilmek için uzaktan eğitimin hızlıca hayata geçirilmesi gerekmiştir (Brooks ve ark., 2020). Bu değişimin hızlı yaşanması nedeniyle öğrenciler açısından uzaktan eğitime ilişkin bilgi ve beceri konusunda değerlendirme yapılamamıştır (Iyer ve ark., 2020). Bu sürecin özellikle uygulama eğitimine sahip olan hemşirelik ve ebelik öğrencileri üzerindeki etkisinin daha farklı olacağ 1 düşünülmektedir. $\mathrm{Bu}$ nedenle öğrencilerin yaşadıkları deneyimlerin farkında olunması ve yaşadıkları sorunlara ilişkin çözüm önerileri sağlanması gerekmektedir (Zan ve Zan, 2020).

\section{Araştırmanın Amacı ve Araştırma Soruları}

$\mathrm{Bu}$ araştırmada COVID-19 pandemi sürecinde hemşirelik ve ebelik bölümlerinde öğrenim gören öğrencilerin uzaktan eğitime yönelik görüş ve önerilerini belirlemek amaçlanmaktadır. Bu amaca yönelik olarak aşağıdaki sorular değerlendirilmiştir. Öğrencilerin;

- Uzaktan eğitim derslerinin işleniş şekilleri nelerdir?

- Uzaktan eğitimde verilen derslerin tamamını izleme durumları nedir?

- Uzaktan eğitim sistemine ilişkin karşılaştıkları problemler nelerdir?

\section{Yöntem}

\section{Araştırmanın Tipi}

$\mathrm{Bu}$ araştırma tanımlayıcı bir çalışmadır.

\section{Araştırmanın Evreni/Örneklemi}

Araştırmanın çalışma evrenini, Türkiye'nin tüm devlet üniversitelerinde öğrenim gören hemşirelik ve ebelik bölümü öğrencileri oluşturmuştur. Örneklemin belirlenmesinde G-Power 3.1.9.7 programı kullanıld1. Programda korelasyon 0.10, tip 1 hata 0.05 ve güç $\% 95$ alındığında 1289 kişi olarak bulundu. Örneklem sayısına ulaşabilmek için amaçlı örnekleme yöntemlerinden biri olan kartopu örnekleme yöntemi kullanılmıştır. Kartopu örneklemi için öncelikli olarak çevremizdeki hemşirelik ve ebelik öğrencilerimiz ile sosyal medya araçları ile iletişime geçildi. Daha sonra bu öğrencilerin tanıdıkları öğrencilere şeklinde örnekleme ulaşılmıştır. Araştırmacılar Akdeniz bölgesinde bulunduğu için örneklem yoğunluğu Akdeniz bölgesindendir. Anketler öğrencilere Google Formlar üzerinde oluşturularak online olarak gönderilmiştir. Araştırma örneklemini 25 Ağustos-20 Aralık 2020 tarihleri arasında araştırmaya alınma kriterlerine uyan 1476 hemşirelik ve ebelik öğrencisi olușturmuștur. Araştırmaya alınma kriterleri; çalışmaya katılmayı kabul etmek, hemşirelik ve ebelik öğrencisi olmak 
ve internet ortamındaki anketi tam olarak doldurmaktır.

\section{Araştırmanın Veri Toplama Araçları}

Araştırmanın konusu ile ilgili daha önce yapılan çalışmalar esas alınarak yapılan literatür taraması ile anket formu oluşturulmuştur (Cao ve ark., 2020; Wang ve ark., 2020; Genç ve Gümrükçüoğlu, 2020; Zan ve Zan, 2020; Keskin ve Kaya, 2020; Karakuş ve ark., 2020). Anket formu, iki bölümden ve toplamda 19 sorudan oluşmaktadır. Birinci bölümde hemşirelik ve ebelik öğrencilerinin tanıtıcı bilgilerinin, ikinci bölümde uzaktan eğitime ilișkin görüşlerinin sorgulandığı sorular yer almaktadır. Anket formundaki sorular çalışmanının amacına uygunluğu ve anlışılırlığı değerlendirilmek üzere sağlık bilimleri alanındaki iki uzmana gönderilmiştir. Uzman değerlendirmesi sonrası sorulardaki yazım ve anlatım bozukluğu olan cümleler yeniden gözden geçirilmiş ve son hali verilerek uygulanmıştır.

\section{Verilerin Değerlendirilmesi}

Verilerin analizi SPSS 21 paket programı ile yapılmıştır. Veriler, sıklık, yüzdelik, ortalama ve kikare testi ile değerlendirilmiştir. Sonuçlar $\mathrm{p}<0.05$ anlamlılık düzeyinde değerlendirilmiştir.

\section{Bulgular}

Araștırmaya katılan hemşirelik ve ebelik öğrencilerinin kişisel özelliklerine göre dağılımı incelendiğinde yaş ortalaması $21.07 \pm 1.92, \% 41.1$ 'i 18-20 yaş aralığında, \%81.3'ü kadın, \%75.1'i hemşirelik öğrencisi, \%52.4'ü ikinci sınıf, \%44.6's1 Akdeniz bölgesinde okuyor, \%89.4'ü COVID-19 izolasyon sürecini ailesinin yanında geçirmiştir. Ailesinin yanında bulunmayanların \%48.6'sının bulunduğu şehirde çıkış yasağı olması nedeniyle ailesinin yanında olamadıklarını ifade ettikleri belirlenmiştir (Tablo 1).

Tablo 1. Hemşirelik ve ebelik öğrencilerinin tanıtıcı özelliklerine göre dağılımı (N=1476)

\begin{tabular}{|c|c|c|}
\hline Kişisel Özellikler & $\mathbf{N}$ & $\%$ \\
\hline Yaş $(\overline{\mathrm{X}} \pm \mathbf{S S})$ & \multicolumn{2}{|c|}{$21.07 \pm 1.92$} \\
\hline $18-20$ & 622 & 42.1 \\
\hline 21 & 432 & 29.3 \\
\hline$>22$ & 422 & 28.6 \\
\hline \multicolumn{3}{|l|}{ Cinsiyet } \\
\hline Kadın & 1200 & 81.3 \\
\hline Erkek & 276 & 18.7 \\
\hline \multicolumn{3}{|l|}{ Bölüm } \\
\hline Hemşirelik & 1108 & 75.1 \\
\hline Ebelik & 368 & 24.9 \\
\hline \multicolumn{3}{|l|}{ Sinıf } \\
\hline Birinci sinıf & 250 & 16.9 \\
\hline İkinci sınıf & 774 & 52.4 \\
\hline Üçüncü sınıf & 360 & 24.4 \\
\hline Dördüncü sınıf & 92 & 6.2 \\
\hline \multicolumn{3}{|l|}{ Üniversitenin bulunduğu bölge } \\
\hline Akdeniz Bölgesi & 658 & 44.6 \\
\hline Ege Bölgesi & 274 & 18.6 \\
\hline İç Anadolu Bölgesi & 162 & 11.0 \\
\hline Doğu Anadolu Bölgesi & 136 & 9.2 \\
\hline Karadeniz Bölgesi & 96 & 6.5 \\
\hline Marmara Bölgesi & 92 & 6.2 \\
\hline Güneydoğu Anadolu Bölgesi & 58 & 3.9 \\
\hline \multicolumn{3}{|l|}{ COVID-19 izolasyon sürecinde bulunduğu yer } \\
\hline Ailenin yanında & 1320 & 89.4 \\
\hline Okuduğu şehirde & 120 & 8.1 \\
\hline Farklı bir şehirde arkadaş/akrabanın yanında & 36 & 2.4 \\
\hline \multicolumn{3}{|c|}{ İzolasyon sürecinde ailenin yanında bulunmama nedeni } \\
\hline Bulunduğum şehirde çıkış yasağının olmasından & 76 & 48.6 \\
\hline Ailemin yanında rahat olamayacağımdan & 38 & 24.5 \\
\hline Ailemin yanında internet erişiminin olmamasından & 22 & 14.1 \\
\hline Farklı bir şehirde çalıştığım için & 20 & 12.8 \\
\hline
\end{tabular}


Araştırmada katılımcıların \%69'unun pandemi sürecinden önce hiç uzaktan/online eğitim almadığ1, \%61.4'ünün pandemi sürecinde hem online, hem ödev, hem de video gönderimi ile dersleri işledikleri, uzaktan eğitimde uygulanan ders anlatım yöntemlerinden hangisini daha yararlı buldukları sorulduğunda \%54.2'sinin canlı ders anlatımlarını daha yararlı bulduğu belirtilmiştir. Katılımcıların \%68.7'sinin uzaktan eğitim derslerinin tamamını izleyemedikleri, izleyememe nedenlerine bakıldığında \%41.2'sinin ev ortamında derse konsantre olamamas1, \%31'inin derslere verdikleri önemin azalması, \%27'sinin başka sorumluluklarının olması nedeniyle izleyemedikleri görülmektedir. Katılımcıların \%84'ünün uzaktan eğitim sürecinde en az bir kez teknik sorun yaşadığ1, en çok yaşanan teknik problemlerin $\% 60.9$ oranında görüntü donması, $\% 59.9$ oranında ses gelmemesi ve \%55.3 oranında internet bağlantısının kopması olduğu, bu yaşanılan teknik sorunları nasıl çözdükleri incelendiğinde ise ilk 3 çözüm yönteminin deneme yanılma yöntemini kullanarak, \%56.9'unun arkadaşından destek alarak ve \%32.4'ünün ilgili dersin hocasıyla iletişim kurarak çözdüğü bulunmuștur (Tablo 2).

Tablo 2. Hemşirelik ve ebelik öğrencilerinin pandemi sürecinde uzaktan eğitime ilişkin görüşleri $(\mathrm{N}=1476)$

\begin{tabular}{|c|c|c|}
\hline Uzaktan Eğitime İlişkin Görüşler & $\mathbf{N}$ & $\%$ \\
\hline \multicolumn{3}{|l|}{ Pandemi sürecinden önce uzaktan/online eğitim alma durumu } \\
\hline Evet & 458 & 31.0 \\
\hline Hayır & 1018 & 69.0 \\
\hline \multicolumn{3}{|l|}{ Pandemi sürecinde uzaktan eğitimi derslerini işleme yöntemi } \\
\hline Hem online hem ödev hem de video gönderimi & 906 & 61.4 \\
\hline Sadece ödev ve video gönderimi & 308 & 20.9 \\
\hline Online canlı ders & 228 & 15.4 \\
\hline Hiç ders yapmadık & 34 & 2.3 \\
\hline \multicolumn{3}{|c|}{ Uzaktan eğitimde uygulanan ders anlatım yöntemlerinden hangisini daha yararlı bulduğu } \\
\hline Canlı ders anlatımları & 800 & 54.2 \\
\hline Canlı olmayan video kayıt ders anlatımları & 586 & 39.7 \\
\hline Hiçbiri & 90 & 6.1 \\
\hline \multicolumn{3}{|l|}{ Uzaktan eğitimde verilen derslerin tamamını izleme durumu } \\
\hline Evet & 462 & 31.3 \\
\hline Hayır & 1014 & 68.7 \\
\hline \multicolumn{3}{|l|}{ Uzaktan eğitimde verilen derslerin tamamını izleyememe nedeni* } \\
\hline Ev ortamında derse konsantre olamama & 608 & 41.2 \\
\hline Pandemi döneminde derslere verilen önemin azalması & 458 & 31.0 \\
\hline Başka sorumluluklarının olması & 398 & 27.0 \\
\hline İnternet kotamın yetersiz olması & 356 & 24.1 \\
\hline Elektronik cihazı aynı anda kullanacak birden fazla kişinin olması & 314 & 21.3 \\
\hline İnternetimin olmamasi & 274 & 18.6 \\
\hline Psikolojik sorunlar & 230 & 15.6 \\
\hline Sağlık sorunları & 70 & 4.7 \\
\hline Sistemsel sorunlar & 28 & 1.9 \\
\hline \multicolumn{3}{|l|}{ Uzaktan eğitim sürecinde teknik sorun yașama durumu } \\
\hline Evet & 1240 & 84.0 \\
\hline Hayır & 236 & 16.0 \\
\hline \multicolumn{3}{|l|}{ Uzaktan eğitim sürecinde en çok hangi teknik problemle karşılaştığı* } \\
\hline Hiçbir teknik sorun yaşamadım & 236 & 16.0 \\
\hline Görüntü donması & 900 & 60.9 \\
\hline Ses gelmemesi & 884 & 59.9 \\
\hline İnternet bağlantısının kopması & 816 & 55.3 \\
\hline Sistemin sanal sınıftan otomatik çıkarması & 532 & 36.0 \\
\hline Hocanın gönderdiği sunum, makale vb. dosyaları açamama & 400 & 27.1 \\
\hline Sınav/ödev dosyalarını sisteme yükleyememe & 342 & 23.2 \\
\hline \multicolumn{3}{|c|}{ Uzaktan eğitimde teknik bir sorunla karșılaștığında bunu nasıl çözdüğ̈̈̈* } \\
\hline Üniversitedeki ilgili birimle iletişim kurdum & 232 & 17.1 \\
\hline Danışman hocam ile iletişim kurdum & 174 & 11.8 \\
\hline İlgili dersin hocasıyla iletişim kurdum & 478 & 32.4 \\
\hline Arkadaşımdan destek aldım & 840 & 56.9 \\
\hline Ailemden destek aldım & 118 & 8.0 \\
\hline Kendim deneme yanılma yöntemiyle çözdüm & 878 & 59.5 \\
\hline
\end{tabular}

* Birden fazla cevap verildiği için yüzdeler $n$ üzerinden hesaplanmıştır. 
Katılımcıların uzaktan eğitim sistemini, hangi internet erişim kaynağ 1 ile takip ettiğine bakıldığında \%71.4'ünün wifi kullandığg, sadece uzaktan eğitim için kullanılan internet kotas1 değerlendirildiğinde \%63.6'sının 6 GB'dan fazla olduğu görülmektedir. Uzaktan eğitim dönemi sona erdiğinde genel not ortalamasındaki değişime bakıldığında \%68.8'inin not ortalamasının arttığ1, genel olarak üniversitenin sağladığı uzaktan eğitim hizmetinden memnun olma durumu değerlendirildiğinde katılımcıların \%32.7'sinin kararsız olduğu, \%23.4'ünün memnun olduğu, kat1lımciların \%23.2'sinin salgından sonra üniversite eğitiminin tümüyle online olarak verilmesini istediği bulunmuş̧tur (Tablo 3 ).

Tablo 3. Hemşirelik ve ebelik öğrencilerinin uzaktan eğitime ilişkin görüşleri ve memnuniyet durumları $(\mathrm{N}=1476)$

\begin{tabular}{|c|c|c|}
\hline & $\mathbf{N}$ & $\%$ \\
\hline \multicolumn{3}{|l|}{$\begin{array}{l}\text { Uzaktan eğitim sistemini, hangi } \\
\text { internet erişim kaynağı ile takip } \\
\text { ettiği* }\end{array}$} \\
\hline Wifi & 1054 & 71.4 \\
\hline Telefonun internet erişimi & 776 & 52.6 \\
\hline YÖK/Üniversitesnin sağladığı kota & 80 & 5.4 \\
\hline \multicolumn{3}{|l|}{$\begin{array}{l}\text { Sadece uzaktan eğitim için aylık } \\
\text { kullanılan internet kotası }\end{array}$} \\
\hline 1 GB'dan az & 38 & 2.6 \\
\hline $1-3 \mathrm{~GB}$ & 184 & 12.5 \\
\hline $3-6 \mathrm{~GB}$ & 316 & 21.4 \\
\hline 6 GB'dan fazla & 938 & 63.6 \\
\hline \multicolumn{3}{|l|}{$\begin{array}{l}\text { Uzaktan eğitim dönemi sona } \\
\text { erdiğinde genel not } \\
\text { ortalamasındaki değişim }\end{array}$} \\
\hline Artt1 & 1016 & 68.8 \\
\hline Değișmedi & 314 & 21.3 \\
\hline Azald 1 & 146 & 9.9 \\
\hline \multicolumn{3}{|l|}{$\begin{array}{l}\text { Genel olarak üniversitenizin } \\
\text { sağladığı uzaktan eğitim } \\
\text { hizmetinden memnun olma } \\
\text { durumu }\end{array}$} \\
\hline Hiç memnun değilim & 176 & 11.9 \\
\hline Memnun değilim & 238 & 16.1 \\
\hline Kararsızım & 482 & 32.7 \\
\hline Memnunum & 346 & 23.4 \\
\hline Tamamen memnunum & 234 & 15.9 \\
\hline \multicolumn{3}{|l|}{$\begin{array}{l}\text { Salgından sonra üniversite } \\
\text { eğitiminin tümüyle online olarak } \\
\text { verilmesini isteme durumu }\end{array}$} \\
\hline Evet & 342 & 23.2 \\
\hline Hayır & 1134 & 76.8 \\
\hline
\end{tabular}

\section{Tartıșma}

Pandemi nedeniyle zorunlu olarak başlanan dijital öğrenme deneyimlerinden çıkarılan derslerin, tüm dünyada bu yöntemin geliştirilmesinde katkı sağlayabileceği düşünülmektedir. Ayrıca yakın gelecekte yeni teknolojilerin geliştirilmesiyle birlikte dijital öğrenmenin temel öğrenme yapısı haline gelebileceği belirtilmektedir (Telli ve Altun, 2020). Ancak, bu sürecin doğru yapılandırılabilmesi için öğrencilerin kullandıkları bilgi teknolojilerinin neler olduğunun, bu süreçte yaşadıkları deneyimlerin ve zorlukların belirlenmesi gerekmektedir. $\mathrm{Bu}$ nedenle çalışmamızda, hemşirelik ve ebelik öğrencilerinin COVID-19 pandemisinde uzaktan eğitime ilişkin görüş ve önerilerini belirlemeyi amaçladık.

Araştırmaya katılan öğrencilerin \%69'u pandemi sürecinden önce hiç uzaktan/online eğitim almadığını ifade etmektedirler. Öğretmen adayları ile yapılan bir çalışmada, katılımcıların \%50'sinin uzaktan eğitime ilişkin daha önceki süreçte çok az deneyime sahip oldukları görülmektedir (Karakuş ve ark., 2020). Ülkemizde uygulama derslerine sahip bölümlerde uzaktan eğitimin yürütülmesinin yeni olması nedeniyle bu oranların düşük olması doğaldır.

Pandemik süreçte belirsizlik ve virüsün bulaşmasını önlemeye yönelik tedbir alma kaygısı öğrencilerin derslerine olan ilgisini azaltmaktadır (Cao ve ark., 2020; Wang ve ark., 2020). Çalışmaya katılan öğrencilerin yarıdan fazlasının uzaktan eğitim derslerinin tamamını izleyemedikleri, izleyemeyenlerin nedenlerine bakıldığında ilk sıralarda ev ortamında derse konsantre olamaması, derslere verdikleri önemin azalması ve başka sorumluluklarının olması olduğu görülmektedir. Farklı araştırmalarda da öğrencilerin yarıdan fazlasının uzaktan eğitimde derslere yeteri kadar katılamadıkları belirtilmektedir (Genç ve Gümrükçüoğlu, 2020; Zan ve Zan, 2020). Andsoy ve arkadaşlarının (2012) çalışmasında uzaktan eğitimin dezavantaji olarak derslere konsantre olamamaları belirtilmektedir. Başka bir çalışmada özellikle kız öğrencilerin yemek yapma, ev temizliği gibi ev işleri yapmaları ve aile üyelerine bakım vermeleri nedeniyle uzaktan eğitime odaklanma sorunu yaşadıkları saptanmıştır (Sever ve Özdemir, 2020). Diğer bir çalışmada derse katılamama nedenleri; sakin ve sessiz bir ortam bulamamalar1, motivasyonlarının düşük olması, bilgisayarının ve internetinin olmaması ve ev ortamında ders dinleme disiplinini sağlayamamaları olarak gösterilmektedir 
(Genç ve Gümrükçüoğlu, 2020; Zan ve Zan, 2020; Kürtüncü ve Kurt, 2020; Karakuş ve ark., 2020).

Çalışmamızda katılımcıların yarıdan fazlasının (\%61.4) pandemi sürecinde hem online, hem ödev, hem de video gönderimi ile dersleri işledikleri, \%20.9'unun sadece video ve ödev gönderimi yaptığ 1 bulunmuştur. Uzaktan eğitimde uygulanan ders anlatım yöntemlerinden hangisini daha yararlı buldukları sorulduğunda yarıdan fazlasının canlı ders anlatımlarını daha yararlı bulduğu belirtilmiştir. Pınar ve Akgül'ün (2020) çalışmasında öğrencilerin $\% 87.7$ 'si en çok canlı derslerden fayda sağladıklarını düşünmektedirler. Canlı derslerin gerek duyulduğunda öğretim elemanına soru sormaya firsat verdiği ve etkileşim sağlayabilme imkanı tanıdığı için öğrenciler tarafından daha faydalı olarak görüldügü düşünülmektedir

Uzaktan eğitimin birçok üniversite için yeni olmadığ1 (Kırkan ve Kalelioğlu, 2017), ancak pandemi nedeniyle acil planlama gerektirdiği için kurumları zorladığ sadece kurumları değil, dünyadaki tüm öğrencilerin neredeyse aynı saatlerde internet erişimine ihtiyaç duyması nedeniyle internet ve uzaktan eğitim alt yap1 koşullarını da zorlamıştır (Sahu, 2020). Çalışmamızda uzaktan eğitim sürecinde en çok yaşanan teknik problemlerin görüntü donmas1, ses gelmemesi ve internet bağlantısının kopması olduğu bulunmuştur. $\mathrm{Bu}$ yaşanılan teknik sorunları nasıl çözdükleri incelendiğinde ilk üç sırada deneme yanılma yöntemiyle çözdüğü, arkadaşından destek aldı ̆̆ı, ilgili dersin hocasıyla iletişim kurduğu yer almaktadır. Uzaktan eğitim sürecinde öğrencilerin etkin bir şekilde dersleri yürütebilmeleri internet bağlantısının kalitesi ile doğrudan ilişkilidir. Birçok çalışma sonuçlarına göre öğrencilerin büyük çoğunluğu az veya çok internet problemi yaşamıştır (Genç ve Gümrükçüoğlu, 2020; Kürtüncü ve Kurt, 2020; Keskin ve Kaya, 2020). Karakuş ve ark. (2020) çalışmasında en sık yaşanılan teknik aksaklıkların internet/bağlantı sorunu ve desteklenmeyen cihaz/donanım eksikliği olduğu sonucuna ulaşılmıştır. Yapılan bir çalışmada, derslere bağlanma ve bilgisayar kullanımında öğrencilerin \%35,1'i bir başkasından destek alırken, \%64,9'unun herhangi bir yardım almadıkları görülmektedir (Genç ve Gümrükçüoğlu, 2020). Uygulama ve teorik derslerin tamamı için uzaktan eğitim yeni olmasına rağmen, üniversite eğitimi alan öğrencilerin teknolojiye aşina olmaları sayesinde, yaşadıkları sorunların çözümünü çoğunlukla kendi kendilerine buldukları düşünülmektedir.
Çalışmamızda öğrencilerin internet erişim kaynaklarının ilk sırada wifi (\%71.4), ikinci sırada ise telefon interneti takip etmektedir. Çalışmamıza benzer şekilde Zan ve Zan (2020) çalışmasında öğrencilerin kullandıkları internet türlerine bakıldığında, \%60'ı ev internetini, \%30'unun cep telefonlarının internet kotalarını kullandığ 1 belirtilmektedir. Günümüzde ak1llı cep telefonlarının kullanımındaki artışla beraber, telefona tanımlı internet kotaları da artış göstermiştir. $\mathrm{Bu}$ nedenle evde wifi erişimi olmayan kişiler telefonlarındaki internet kotalarından destek almaktadırlar.

Çalışmamızda katılımcıların çoğunluğunun salgından sonra üniversite eğitiminin tümüyle online olmasını istemedikleri bulunmuştur. Çalışmamıza benzer şekilde Pınar ve Akgül'ün (2020) çalışmasında öğrencilerin tamamına yakını fen derslerini okulda yapılmasının daha faydalı olduğunu düşünmektedirler. Başka bir çalışmada öğrencilerin yarıdan fazlası yüz yüze eğitimi tercih ederken, \%25.3'ünün uzaktan eğitimi tercih ettiği görülmektedir (Zan ve Zan, 2020). Karakuş ve ark. (2020), çalışmasında öğrencilerim \%62'sinin yüz yüze eğitimi daha çok tercih ettiği, katılımcıların üçte birininde yüz yüze ve uzaktan eğitimin bir arada olduğu karma yöntemi istedikleri görülmektedir. Fizyoterapi ve rehabilitasyon bölümlerinde okuyan öğrencilerle yapılan bir çalışmada, nedeyse tamamının (\%90.3) yüz yüze eğitime geri dönmek istedikleri ifade edilmektedir (Y1lmaz, 2020). Meslek Yüksekokulu öğrencilerine 2016 yılında yapılan bir çalışmada, koşulların uygun olması durumunda öğrencilerin \%85.2'sinin örgün eğitimi, \%14.7'sinin uzaktan eğitimi tercih edebilecekleri belirtilmektedir (Özyürek ve ark., 2016). Uygulamalı eğitim olan hemşirelik ve ebelik öğrencileri için teorik dersleri dinledikten sonra hastanede uygulama yapmalarının, mesleki uygulama becerilerini daha iyi geliştirebileceğinin farkında oldukları için yüz yüze eğitimi tercih ettikleri düşünülmektedir.

\section{Sonuç}

Hemşirelik ve ebelik öğrencilerinin en çok canlı dersleri faydalı buldukları, ders sırasında özellikle bağlantı kopması, görüntü donması, ses gitmesi gibi teknik problemler yaşadıkları görülmektedir. Öğrencilerin daha sonraki eğitim sürecinde çoğunluğunun yüz yüze eğitime geri dönmek istedikleri görülmektedir. Sonuçlar doğrultusunda aşağıdakiler önerilmektedir. 
- Öğrencilerin uzaktan eğitimden daha iyi faydalanabilmeleri için gerekli teknolojik desteğin sağlanması,

- Üniversitelerin uzaktan eğitime ilişkin gerekli alt yapı değişikliklerini yapması,

- Hemşirelik ve ebelik bölümlerinde çalıșan öğretim üyelerinin üniversitelerinin koşulları doğrultusunda sonraki dönemler için yeni çözümler geliştirmeleri,

- Hemşirelik öğretiminde uzaktan ve yüz yüze eğitimin bir arada yürütülebilmesi durumuna ilişkin araştırmalar yapılması önerilmektedir.

\section{Araştırmanın Sınırlılıkları}

Araştırmanın bazı sınırlılıkları bulunmaktadır. İlk olarak çalışmaya katılım gönüllülük esasına bağlı olduğu için hemşirelik ve ebelik öğrencilerinin oranlarının eşit olmaması karşılaştırmada sınırlılık oluşturmuştur. Bir diğeri ise verilerin online toplanması nedeniyle internet erişimi olmayan ve iletişim adreslerine erişilemeyen öğrencilere ulaşılamamıştır. Bu nedenle araştırma sonuçları tüm hemşirelik ve ebelik öğrencilerine genellenmemelidir.

\section{Teşekkür}

Araştırmaya katılan hemşirelik ve ebelik öğrencilerine verdikleri katkıdan dolayı teşekkür ederiz.

Araştırmanın Etik Yönü/ Ethics Committee Approval: Araştırmanın yürütülebilmesi için, araştırmaya başlamadan önce Burdur Mehmet Akif Ersoy Üniversitesi Girişimsel Olmayan Klinik Araştırmalar Etik Kurulu'ndan (Tarih: 20.08.2020; Karar No: GO 2020/186), Sağlık Bakanlığı Bilimsel Araştırma Kurulu'ndan ve araştırmaya katılmayı kabul eden öğrencilerden izin alınmıştır. Makalede araştırma ve yayın etiğine uyulmuştur.

Hakem/Peer-review: Dıș hakem değerlendirmesi.

Yazar Katkısı/Author Contributions: Fikir/kavram: NT; Tasarım: NT, SUY; Danışmanlık: NT, SUY; Veri toplama: NT, SUY; Veri İşleme NT, SUY; Analiz ve/veya Yorum: NT; Kaynak tarama; NT, SUY; Makalenin Yazımı: NT, SUY; Eleştirel inceleme: NT.

Çıkar çatışması/Conflict of interest: Çalışmada herhangi bir çıkar çatışması söz konusu değildir.

Finansal Destek/Financial Disclosure: $\mathrm{Bu}$ çalıșma herhangi bir kurum ya da kuruluş tarafından desteklenmemiş̧tir.

\section{Çalışma Literatüre Ne Kattı?}

- Bu araştırma hemşirelik ve ebelik öğrencilerinin COVID- 19 pandemi sürecindeki uzaktan eğitime yönelik mevcut durumu ortaya koymak, eksikleri belirlemek, gelecek dönemler için öğrencilerin daha iyi eğitim alabilmeleri açısından önemlidir. Araştırma bu amaçla hazırlanmıș olup yapılacak girişimler ve alınacak önlemlere temel oluşturacağ 1 öngörülmektedir.

- Çalışma bulgularımız uzaktan eğitim ile ilgili öğrencilerin yaşadıkları sorunları belirleyerek, devam eden süreçte daha iyi eğitim sağlayabilmek için alınabilecek önlemlere ilişkin çözüm önerisi getirebileceği düşünülmektedir.

- Uzaktan eğitim daha önceki yıllarda da yapılırken tüm derslerin uzaktan eğitimle yürütülmesi yeni bir durumdur. Bu süreçten sonra özellikle olağanüstü durumlarda ve salgınlarda tamamen uzaktan eğitimin kullanılabileceği düşünülmektedir. Bu açıdan çalışma bulgularımız uzaktan eğitime ilişkin öğrenci görüşlerine dayalı mevcut duruma ve eksikliklere ilişkin literatüre katkı sağlayacaktır.

\section{Kaynaklar}

Andsoy II, Güngör T, Bayburtluoğlu T, Yaman S. (2012). Karabük Üniversitesi Sağlık Yüksekokulu birinci sınıf hemşirelik öğrencilerinin uzaktan eğitim sistemine ilişkin düşünceleri. Türkiye Klinikleri Hemşirelik Bilimleri Dergisi, 4(2), 66-73.

Brooks SK, Smith LE, Webster RK, Weston D, Woodl L, Hall I. ve ark. (2020). The impact of unplanned school closure on children's social contact: Rapid evidence review. Eurosurveillance, 25(13), 1-10.

Cao W, Fang Z, Hou G, Han M, Xu X, Dong J. ve ark. (2020). The psychological impact of the COVID-19 epidemic on college students in China. Psychiatry Research, 287 (112934), 1-6.

Chen S, Yang J, Yang W, Wang C, Bärnighausen T. (2020). COVID-19 control in China during mass population movements at New Year. Lancet, 395(10226), 764-766.

Genç MF, Gümrükçüoğlu S. (2020). Koronavirüs (COVID-19) sürecinde ilâhiyat fakültesi öğrencilerinin uzaktan eğitime bakışları. Electronic Turkish Studies, 15(4), 403-422.

Iyer P, Aziz K, Ojcius DM. (2020). Impact of COVID-19 on dental education in the United States. Journal of Dental Education, 84(6), 718-722.

Karakuş N, Ucuzsatar N, Karacaoğlu MÖ, Esendemir N, Bayraktar D. (2020). Türkçe öğretmeni adaylarının uzaktan eğitime yönelik görüşleri. RumeliDE Dil ve Edebiyat Araştırmaları Dergisi, (19), 220-241. 
Keskin M, Kaya DÖ. (2020). COVID-19 sürecinde öğrencilerin web tabanlı uzaktan eğitime yönelik geri bildirimlerinin değerlendirilmesi. İzmir Katip Çelebi Üniversitesi Sağlık Bilimleri Fakültesi Dergisi, 5(2), 59-67.

Kirkan B, Kalelioglu F. (2017). Türkiye'de uzaktan eğitim merkezlerinin durumu: Betimsel bir çalışma. Journal of Instructional Technologies \& Teacher Education JITTE, 6(3), 88-98.

Kurnaz E, Serçemeli M. (2020). COVID-19 pandemi döneminde akademisyenlerin uzaktan eğitim ve uzaktan muhasebe eğitimine yönelik bakış açıları üzerine bir araştırma. Uluslararası Sosyal Bilimler Akademi Dergisi, 3(3), 262-288.

Kürtüncü M, Kurt A. (2020). COVID-19 pandemisi döneminde hemşirelik öğrencilerinin uzaktan eğitim konusunda yaşadıkları sorunlar. Avrasya Sosyal ve Ekonomi Araştırmaları Dergisi, 7(5), 66-77.

Öztürk D. (2015). Uzaktan eğitime hemşirelik eğitimi penceresinden bir bakış. Anadolu Hemşirelik ve Sağlık Bilimleri Dergisi, 18(3), 229-234.

Özyürek A, Begde Z, Yavuz NF, Özkan İ. (2016). Uzaktan eğitim uygulamasının öğrenci bakış açısına göre değerlendirilmesi. Karabük Üniversitesi Sosyal Bilimler Enstitüsü Dergisi, 6(2), 595-605.

Pınar MA, Akgül GD. (2020). The opinions of secondary school students about giving science courses with distance education during the COVID-19 pandemic. Journal of Current Researches on Social Sciences, 10(2), 461-486.

Sahu P. (2020). Closure of universities due to coronavirus disease 2019 (COVID-19): Impact on education and mental health of students and academic staff. Cureus, 12(4), 1-6.

Sever M, Özdemir S. (2020). Koronavirüs (COVID-19) sürecinde öğrenci olma deneyimi: Bir fotoses (photovoice) çalışması. Toplum ve Sosyal Hizmet, 31(4), 1653-1679.
T.C. Sağlık Bakanlığı Halk Sağlığı Genel Müdürlüğü. COVID-19 (SARSCoV2 Enfeksiyonu) Rehberi, Bilim Kurulu Çalışması. Erişim tarihi:16.10.2020, https://covid19bilgi.saglik.gov.tr/depo/rehberler/covi d-19_Rehberi.pdf

Telli SG, Altun D. (2020). Coronavirüs ve çevrimiçi (online) eğitimin önlenemeyen yükselişi. Üniversite Araştırmaları Dergisi, 3(1), 25-34.

Viner RM, Russell SJ, Croker H, Packer J, Ward J, Stansfield C, ve ark. (2020). School closure and management practices during coronavirus outbreaks including COVID-19: A rapid systematic review. The Lancet Child \& Adolescent Health, 4, 397-404.

Wang C, Cheng Z, Yue XG, McAleer M. (2020). Risk management of COVID-19 by universities in China. Journal of Risk and Financial Management, 13(2), 16.

Yılmaz NA. (2020). Yükseköğretim kurumlarında COVID-19 pandemisi sürecinde uygulanan uzaktan eğitim durumu hakkında öğrencilerin tutumlarının araştırılması: Fizyoterapi ve rehabilitasyon bölümü örneği. Necmettin Erbakan Üniversitesi Sağlık Bilimleri Fakültesi Dergisi, 3(1), 15-20.

Zan N, Zan BU. (2020). Koronavirüs ile acil durumda eğitim: Türkiye'nin farklı bölgelerinden uzaktan eğitim sistemine dahil olan edebiyat fakültesi öğrencilerine genel bakış. Electronic Turkish Studies, 15(4), 1367-1394.

Zhong BL, Luo W, Li HM, Zhang Q, Liu XG, Li WT. ve ark. (2020). Knowledge, attitudes, and practices towards COVID-19 among Chinese residents during the rapid rise period of the COVID-19 outbreak: A quick online cross- sectional survey. International Journal of Biological Sciences, 16(10), 1745-1752.

Zhu N, Zhang D, Wang W, LI X, Yang B, Song J, ve ark. (2020). A novel coronavirus from patients with pneumonia in China. The New England Journal of Medicine, 382 (8), 727-733. 